\title{
The Effects of Aging Temperature on the Corrosion and Electrical Conductivity in the AA7075 Alloy Produced by Powder Metallurgy Method
}

\author{
I. SimseK ${ }^{a *}$, C. NAlCaCioglu ${ }^{b}$ And D. OzYUREK ${ }^{c}$ \\ ${ }^{a}$ Karabuk University, TOBB Tech. Sci. Voc. Sch., Program of Mach. and Metal Tech., 78050 Karabuk, Turkey \\ ${ }^{b}$ Karabuk University, Graduate School of Natural and Applied Sciences, 78050 Karabuk, Turkey \\ ${ }^{c}$ Karabuk University, Technology Faculty, Department of Manufacturing Eng., 78050 Karabuk, Turkey \\ In this study, the effect of aging temperature of corrosion and electrical conductivity of AA7075 produced by \\ powder metallurgy method was investigated. Produced AA7075 Al alloy samples, obtained by powder metallurgy \\ method, were quenched after solution treatment at $485^{\circ} \mathrm{C}$ for $2 \mathrm{~h}$. Then they were aged at three different tempera- \\ tures $\left(110^{\circ} \mathrm{C}, 120^{\circ} \mathrm{C}\right.$, and $\left.130^{\circ} \mathrm{C}\right)$ for $24 \mathrm{~h}$. Aged samples hardness and density measurements were carried out and \\ they were characterized by scanning electron microscopy, energy dispersive spectroscopy, and X-ray diffraction. \\ Corrosion tests were carried out using potentiodynamic polarization technique, a cyclic polarization measurement \\ at a scan interval of $\pm 750 \mathrm{mV}$ and scan rate of $1 \mathrm{mV} / \mathrm{s}$ in $0.1 \mathrm{M} \mathrm{H}_{2} \mathrm{SO}_{4}$ solution. Electrical conductivity values \\ were calculated (IACS\%) according to ASTM B193-02 standards. As a result of the study, the highest hardness \\ values were measured with aged samples at $120^{\circ} \mathrm{C}$. In addition, the lowest electrical conductivity and the lowest \\ corrosion resistances values were obtained with aged samples at $120^{\circ} \mathrm{C}$.
}

DOI: 10.12693/APhysPolA.135.722

PACS/topics: aging temperature, AA7075, powder metallurgy, corrosion resistance, electrical conductivity

\section{Introduction}

Aluminum and its alloys are the most widely used materials after iron alloys in various fields of industry. The most significant advantage of the $7 \mathrm{xxx}$ series aluminum alloys is that their mechanical properties can be improved. The AA7075 alloy is regarded as an ideal material that is widely used in aviation, defence industry, and some other engineering applications. The primary area of use for AA7075 alloy in these applications includes body and wing parts of high-performance military planes [1]. The most commonly used and accepted heat treatment technique is the T6 heat treatment. However, in this technique the corrosion resistance is affected negatively. Aluminum alloys usually become regionally sensitive to corrosion due to factors such as corrosion between particles, pitting, and stress corrosion cracking. The corrosion resistance is closely related with the alloy's composition [2], heat treatment [3], and working conditions [4]. In addition to corrosion resistance, another important property of these alloys is the electrical conductivity. The main reason behind aluminum's use in numerous applications is its high electrical conductivity. Alloying elements added into aluminum and heat treatments applied to these alloys affect the electrical conductivity. The quality and the quantity of precipitates formed in the structure as a result of heat treatments are parameters determining electrical conductivity as well.

*corresponding author; e-mail: ijlalispir@karabuk.edu.tr
The electrical conductivity of metallic materials depend on factors such as the size and volume rate of precipitates in the structure, pores formed in the structure, and lattice faults [5]. Thus, the purpose of this study is to investigate the effects of aging temperature on the microstructure, hardness, corrosion, and electrical conductivity of the T6 heat treated AA7075 alloy produced with the $\mathrm{P} / \mathrm{M}$ method.

\section{Experimental procedure}

Table I shows the chemical composition of the AA7075 alloy used in the experimental studies.

The chemical composition of the AA7075 alloy

TABLE I

\begin{tabular}{c|c|c|c|c|c|c|c|c|c}
\hline \hline Element & $\mathrm{Zn}$ & $\mathrm{Mg}$ & $\mathrm{Cu}$ & $\mathrm{Fe}$ & $\mathrm{Si}$ & $\mathrm{Zr}$ & $\mathrm{Mn}$ & $\mathrm{Cr}$ & $\mathrm{Al}$ \\
\hline $\mathrm{wt} \%$ & 5.48 & 2.58 & 1.568 & 0.549 & 0.403 & 0.0305 & 0.014 & 0.0125 & bal.
\end{tabular}

AA7075 alloy powders were shaped under $520 \mathrm{MPa}$ pressure, and $\varnothing 12 \times 7 \mathrm{~mm}$ cylindrical samples were produced. The samples were sintered under $10^{-6}$ mbar vacuum at $580^{\circ} \mathrm{C}$. The samples were solution treated at $485^{\circ} \mathrm{C}$ for $2 \mathrm{~h}$, and then rapidly cooled to room temperature. The aging procedure was performed at three different temperatures $\left(110^{\circ} \mathrm{C}, 120^{\circ} \mathrm{C}\right.$, and $\left.130^{\circ} \mathrm{C}\right)$ for $24 \mathrm{~h}$. Following the standard metallographic procedures, the samples were seared with Keller's solution for 15-20 s. Corrosion tests were performed using the potentiodynamic polarization technique with Parstat 4000 computer-controlled potentiostat/galvanostat test device. The samples were kept for 30 min until the open circuit potential (OCP) is reached. Polarization measurements were performed in a corrosion cell using the 
three-electrode setup with SCE reference electrode and a platinum plate counter electrode. $0.1 \mathrm{M} \mathrm{H}_{2} \mathrm{SO}_{4}$ solution was used as the electrolyte environment. A cyclic polarization measurement was carried out within a scanning range of $\pm 750 \mathrm{mV}$ and at $1 \mathrm{mV} / \mathrm{s}$ scan rate. The electrical conductivity was measured as $\mathrm{mV}$, and the conductivity values (IACS\%) were calculated in accordance with the ASTM B193-02 standard.

\section{Results and discussion}

Figure 1 shows the microstructure scanning electron microscopy (SEM) images of the AA7075 alloy and the AA7075 alloys aged at five different temperatures.
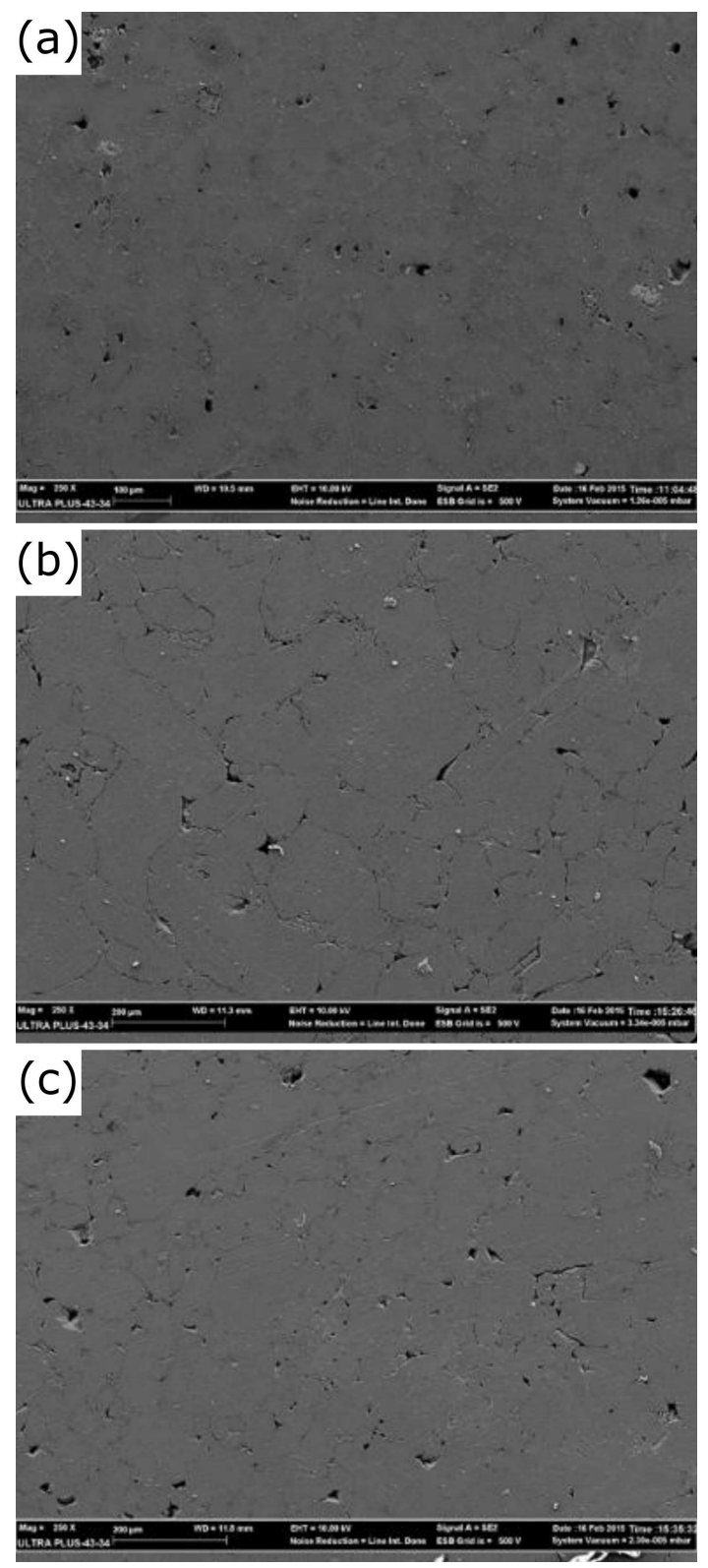

Fig. 1. The SEM images of the AA7075 alloys aged at different temperatures: $110^{\circ} \mathrm{C}(\mathrm{a}), 120^{\circ} \mathrm{C}(\mathrm{b})$, and $130{ }^{\circ} \mathrm{C}(\mathrm{c})$.
As shown in Fig. $1 \mathrm{a}-\mathrm{c}$, second phase $\left(\mathrm{MgZn}_{2}\right)$ precipitates (spherical white dots), expected to form in the structure of the alloy with the heat treatment, formed along grain boundaries and in the grain interiors, although they were very small. Abolhasani et al. [6] reported that various intermetallic compounds formed both in the grain interiors and along grain boundaries in the structure of the AA7075 alloy hot rolled at different temperatures. Also, it was observed that precipitates became more notable with increased aging temperature. It was reported in previous studies that increased aging temperature led to an increase in sizes of precipitates formed in the structure $[7,8]$. Figure 2 shows the X-ray diffraction (XRD) results of the AA7075 alloy aged at $130^{\circ} \mathrm{C}$, and hardness and electrical conductivity changes in the alloys aged at different temperatures.
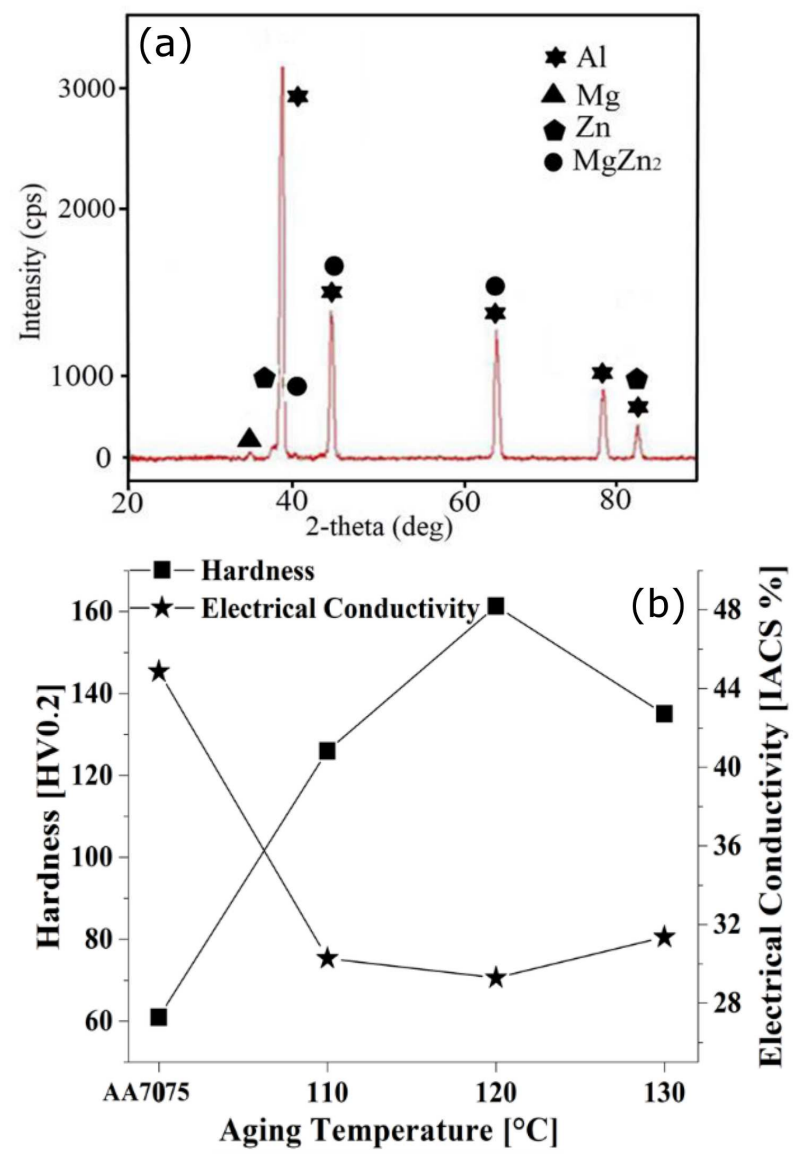

Fig. 2. The XRD results of the AA7075 alloy aged at $130{ }^{\circ} \mathrm{C}(\mathrm{a})$, and hardness and electrical conductivity changes in the alloys aged at different temperatures (b).

The XRD result given in Fig. 2a shows that secondary $\mathrm{MgZn}_{2}$ peaks formed in the structure in addition to $\mathrm{Al}$, $\mathrm{Zn}$, and $\mathrm{Mg}$ peaks. LaDelpha et al. [9] reported that the dominant phases were $\alpha-\mathrm{Al}$ and $\mathrm{MgZn}_{2}$ which have hexagonal unit cell. The researchers also noted that the GP zone of the alloy matrix contained combinations of $\eta$ and $\eta^{\prime}$ however, it was not possible to detect GP zones 
and the phase due to high consistency of these phases with $\alpha$-Al. The hardness changes in Fig. $2 \mathrm{~b}$ shows that the hardness of the alloy increased with increasing aging temperature. This may be explained with the Orowan mechanism. The increase in the volume rate of second phase $\left(\mathrm{MgZn}_{2}\right)$ precipitates in the structure of the alloy prevents dislocation movements, and causes an increase in the strength of the alloy $[10,11]$. Figure $2 \mathrm{~b}$ also shows that the non-heat treated alloy had the highest electrical conductivity value (44.86\%). This is related with the fact that second phase precipitates did not form in the structure since the alloy was not aged. The T6 heat treatment applied to the alloy reduces electrical conductivity. The aging temperature of $110^{\circ} \mathrm{C}$ produced an IACS\% value of $30.28 \%$. According to these results, electrical conductivity and hardness results of the AA7075 alloys aged at different temperatures seem to support each other. Salazar-Guapuriche et al. [5] reported that electrical conductivity of an alloy was related with precipitates formed in the structure with the aging heat treatment. The hardness decreased and the electrical conductivity increased due to the size of precipitates formed in the structure, which depends on the aging temperature [5]. Also, micro and macro-pores formed in the structure of the alloy are believed to be causing the decrease in electrical conductivity in the $\mathrm{P} / \mathrm{M}$ method. Figure 3 shows the polarization Tafel curves for the AA7075 alloys produced with the $\mathrm{P} / \mathrm{M}$ method, and Table II reproduces the corrosion parameters obtained from these curves.

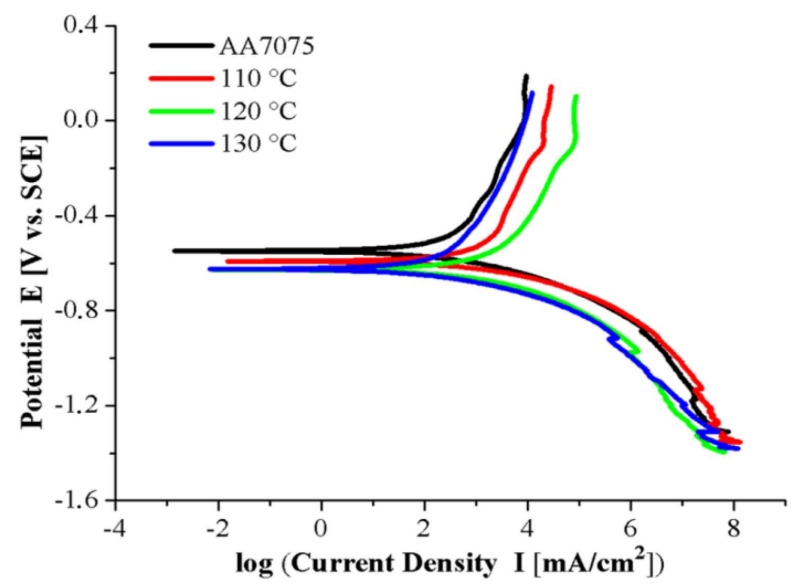

Fig. 3. The Tafel curves for the AA7075 alloy and the alloys aged at different temperatures.

The corrosion parameters obtained from

TABLE II the Tafel curves in Fig. 3.

\begin{tabular}{c|c|c|c|c|c}
\hline \hline Electrode & $\begin{array}{c}E_{\text {corr }} \\
{[\mathrm{mV}]}\end{array}$ & $\begin{array}{c}I_{\text {corr }} \\
{\left[\mathrm{mA} / \mathrm{cm}^{2}\right]}\end{array}$ & $\begin{array}{c}\beta_{a} \\
{[\mathrm{mV}]}\end{array}$ & $\begin{array}{c}\beta_{c} \\
{[\mathrm{mV}]}\end{array}$ & $\begin{array}{c}\text { Corr. rate } \\
{[\mathrm{mm} / \text { year }]}\end{array}$ \\
\hline AA7075 & -549.342 & 191.368 & 178.385 & 1240 & 2.4945 \\
$110^{\circ} \mathrm{C}$ & -591.557 & 349.049 & 1552 & 183.504 & 4.2012 \\
$120^{\circ} \mathrm{C}$ & -628.282 & 492.511 & 1313 & 270.834 & 5.9760 \\
$130^{\circ} \mathrm{C}$ & -624.56 & 192.585 & 1307 & 202.637 & 2.3541
\end{tabular}

As suggested by the polarization Tafel curves shown in Fig. 3a, the current density varied due to increasing aging temperature. Ramgopal et al. [12] reported that the regions containing and not containing precipitates along grain boundaries of a typical aluminum alloy displayed different electrochemical behaviors from each other. This is the most obvious reason behind the increase in the corrosion susceptibility due to the $\mathrm{MgZn}_{2}$ phase formed in the structure because of the T6 heat treatment. Metastable $\mathrm{MgZn}_{2}$ precipitates formed in the structure are anodic and easily dissolved [13]. The corrosion parameters given in Fig. 3b shows that the maximum corrosion rate was $5.9760 \mathrm{~mm}$ /year, which were obtained for the alloy aged at $120^{\circ} \mathrm{C}$. The lowest corrosion rate was obtained for the alloy aged at $130^{\circ} \mathrm{C}$.

\section{Conclusion}

The effects of aging temperature on the microstructure, hardness, corrosion, and electrical conductivity of the T6 heat treated AA7075 alloy produced with the $\mathrm{P} / \mathrm{M}$ method were investigated in this study. The results are given below.

- It was determined with microstructure and XRD studies that second phase precipitates $\left(\mathrm{MgZn}_{2}\right)$ formed in the structure of the alloys aged at different temperatures.

- The hardness of the alloy increased with increasing aging temperature. The highest hardness value was obtained for the alloy aged at $120^{\circ} \mathrm{C}$. The aging temperature of $130^{\circ} \mathrm{C}$ led to a decrease in the hardness value.

- In corrosion tests, the highest corrosion resistance was obtained for the alloy aged at $130^{\circ} \mathrm{C}$, whereas the lowest corrosion resistance was obtained for the alloy aged at $120^{\circ} \mathrm{C}$.

- The electrical conductivity decreased with increasing aging temperature. The highest IACS value $(44.86 \%)$ was obtained for the non-heat treated alloy. Among the heat treated alloys, the highest electrical conductivity was obtained for the alloy aged at $130^{\circ} \mathrm{C}$.

\section{Acknowledgments}

The authors are pleased to acknowledge the financial support for this study from Karabuk University Scientific Research Projects Department (KBÜ-BAP-15/2YL-036).

\section{References}

[1] Y.C. Lin, L.T. Li, Y.X. Fu, Y.Q. Jiang, J. Mater. Sci. 47, 1306 (2012).

[2] H.C. Fang, K.H. Chen, X. Chen, L.P. Huang, G.S. Peng, B.Y. Huang, Mater. Sci. Eng. A 528, 7606 (2011).

[3] Z. Nikseresht, F. Karimzadeh, M.A. Golozar, M. Heidarbeigy, Mater. Des. 31, 2643 (2010).

[4] C. Li, Q.L. Pan, Y.J. Shi, Y. Wang, B. Li, Mater. Des. 55, 551 (2014). 
[5] M.A. Salazar-Guapuriche, Y.Y. Zhao, A. Pitman, A. Greene, Mater. Sci. Forum 519, 853 (2006).

[6] A. Abolhasani, A.Z. Hanzaki, H.R. Abedi, M.R. Rokni, Mater. Des. 34, 631 (2012).

[7] Z.W. Du, Z.M. Sun, B.L. Shao, T.T. Zhou, C.Q. Chen, Mater. Charact. 56, 121 (2006).

[8] M. Yildirim, D. Özyürek, M. Gürü, Arab. J. Sci. Eng. 41, 4273 (2016).

[9] A.D.P. LaDelpha, H. Neubing, D.P. Bishop, Mater. Sci. Eng. A 520, 105 (2009).
[10] Y. Reda, R. Abdel-Karim, I. Elmahallawi, Mater. Sci. Eng. A 485, 468 (2008).

[11] R. Yılmaz, D. Özyürek, E. Kibar, J. Fac. Eng. Archit. 27, 429 (2012).

[12] T. Ramgopal, P.I. Gouma, G.S. Frankel, Corrosion 58, 687 (2002).

[13] A.U. Rao, V. Vasu, M. Govindaraju, K.S. Srinadh, Trans. Nonferrous Met. Soc. China 26, 1447 (2016). 